\title{
PENGISIAN ENERGI LISTRIK UNTUK PENERANGAN DARURAT RUANGAN LABORATORIUM KOMPUTER TEKNIK MESIN UNISKA DAYA MAKSIMUM 500 WATT
}

\author{
${ }^{(1)}$ Gusti Rusydi Furqon Syahrillah, ${ }^{(2)}$ Eko Haryanto \\ (1)(2)Teknik Mesin, Fakultas Teknik, Universitas Islam Kalimantan MAB \\ Jl. Adhiyaksa No. 2 Kayu Tangi, Banjarmasin \\ Email :gustirusyidi@gmail.com, ekoharyanto21@gmail.com
}

\begin{abstract}
Abstrak
Pembangkit Listrik Tenaga Battery adalah suatu perencanaan penyediaan listrik yang digunakan untuk kebutuhan listrik untuk kebutuhan penerangan darurat yang di bantu dengan inverter pada saat aliran listrik dari PLN dalam keadaaan black out/pemadaman. Metode penelitian yang digunakan adalah melakukan penggabungan kedua piranti tersebut dengan di rakit sedemikian rupa melalui instalasi yang di sesuaikan dengan kebutuhan cahaya suatu ruangan dengan daya listrik yang dihasilkan. Daya listrik yang dihasilkan memberikan pengaruh terhadap hasil dan lama penyimpanan dalam energi batterai mampu memberikan daya sebesar 549 watt.
\end{abstract}

Kata Kunci : Energi Listrik, Bateri, Suply energi

\begin{abstract}
Battery Power Plant is a plan for supplying electricity that is used for electricity needs for emergency lighting needs, which is assisted by an inverter when the flow of electricity from the PLN in blackout / blackout conditions. The research method used is to combine the two devices with a raft in such a way through an installation that is adjusted to the light requirements of a room with the electric power generated. The electric power generated has an influence on the results and the storage time in battery energy can provide power of 549 watts.
\end{abstract}

Keywords: Electric Energy, Battery, Energy supply

\section{PENDAHULUAN}

Perkembangan jumlah mahasiswa Fakultas Teknik Universitas Islam Kalimantan Banjarmasin merupakan kampus yang mulai berkembang se iring dengan bertambahnya minat mahasiswa untuk mengenyam pendidikan di Fakultas ini. Dengan demikian di butuhkan peningkatan sarana dan prasarana dalam menunjang pelayanan terhadap mahasiswa.
Salah satu untuk meningkatkan layanan berupa adanya layanan dengan tersedianya energi listrik yang mampu memberikan supply tanpa ada gangguan pemadaman. Cara ini bisa di lakukan melalui ketersediaan instalasi generator sistem, ataupun instalasi panel surya atau Uninterruptible Power Supplies (UPS).

Di dasari atas kebutuhan energi listrik yang dibutuhkan ruangan Fakultas Teknik dan latar belakang di atas maka penulis berinisiatif untuk merancang 
instalasi yang bisa di manfaaatkan sebagai sumber tenaga listrik yang dapat digunakan ketika terjadi pemadamn listrik dari PLN. Alat ini berupa sebuah inverter yang di rakit sedemikian rupa aga bisa mensupply energi listrik tersebut.

Inverter dapat merubah energi listrik dari baterai menjadi energi listrik se arah (AC) yang di aplikasikan dengan memanfaatkan aliran simpanan energi dalam battery. Salah satu cara untuk mengubah tegangan DC menjadi AC adalah dengan menggunakan Inverter. Inverter berfungsi sebagai mengubah tegangan 12 VDC menjadi 220 VAC. Metode pembangkitan gelombang/sinyal menggunakan rangkaian oscillator/Multivibrator yang dirancang dengan frekuensi kerja $50 \mathrm{~Hz}$.

\section{METODE PENELITIAN}

Payung charger di buat berdasarkan spesifikasi umum yang telah banyak di pasarkan, kemudian di rakit berdasarkan fungsi alat di maksud sesuai kebutuhan.

\section{Alat dan Bahan}

1. Inverter $1000 \mathrm{~W}$

INVERTER :

Input : 12V Battery (10-15Volt)

Output : 220VAC

Frekuensy $\quad: 50 \mathrm{~Hz}+/-5 \%$

Low Battery Alarm: 105 Volt (+/-0.5 V)

Low Battery Shutdown : $65^{\circ} \mathrm{C} \quad(+/-5 \mathrm{C})$

CHARGER (On board) :

Input : $160-260 \mathrm{~V}$

Output: 12V DC 5A

Charge Control: Absortion : $14.4 \mathrm{~V}$

Float : 13.8V Start 7V

Spesifikasi: Inverter $1000 \mathrm{~W}$ ini memiliki pesifikasi sebagai berikut : Tegangan nominal input (DC) : $12 \mathrm{~V}$ $(10 \sim 15)$

Tegangan nominal output (AC) : $220 \mathrm{~V}$

AC

Frekuensi : $50 \mathrm{~Hz}$

Battery: 12 Volt $47 \mathrm{AH}$
Kabel : 30 Meter

Saklar : 2 buah

Lampu TL : 2 biji @ 30watt

AVO Meter digital

Tool kit elektrikal : 1 set

Rancangan Arduino

Perancangan Sistem Kontrol Otomatis

Perancangan ini berfokus pada bagaimana membuat suatu rancangan sistem kontrol otomatis on - off. Sistem kontrol yang secara otomatis memerintahkan aliran listrik pada kondisi on jika PLN padam dan off jika PLN menyala. Rancangan ini menggunakan komponen-komponen elektronik seperti : Arduino Uno dengan ATmega 328P, Sensor rintik hujan, Relay 2 Chanel 5V, Bluetooth modul HC-05, HP Android dan Solenoid valve pneumatic tipe 5/2 way single coil. Berikut adalah gambar blok diagram dari sistem yang akan direalisasikan.

\section{HASIL DAN PEMBAHASAN}

Penelitian ini merupakan rancang bangun dengan menggunakan percobaan empriris dengan melihat kondisi aktual dari besar kebutuhan penerangan pada saat tidak ada supply energy listrik dari PLN.

Dari gambar 4.1 denah kantor Fakultas maka di butuhkan 2 titik penerangan yang mampu memberikan intensitas yang cukup dalam ruang

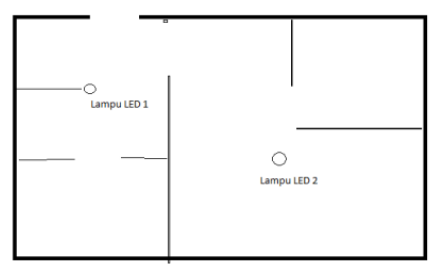

Sehingga rancangan dapat di gambarkan sebagai berikut : 


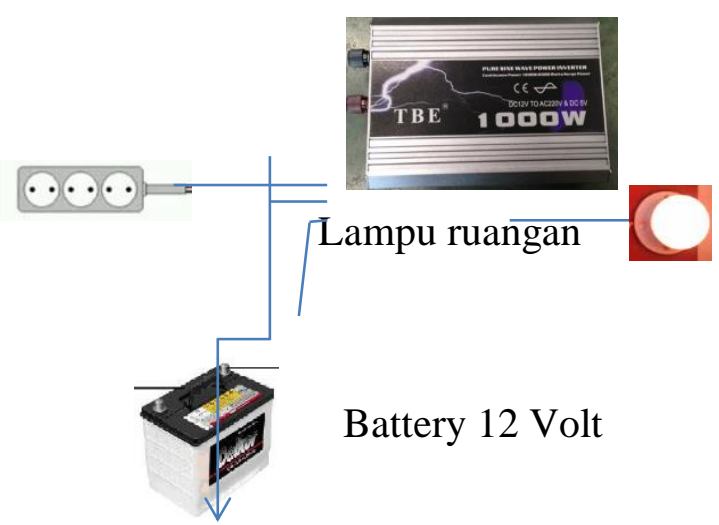

Gambar 2 Rancangan penerangan darurat dengan inverter

Alat ini merupakan penggabungan dari dua buah rangkaian yaitu: rangkaian pengisi batery otomatis (Automatic Baterry Charger) dan rangkaian inverter sebagai rangkaian pengubah tegangan DC $12 \mathrm{~V}$ dari akumulator menjadi tegangan $220 \mathrm{~V}$ AC. Pada rangkaian pengisi batery otomatis, batery akan diisi oleh catu daya dari PLN 220V AC yang sudah diturunkan tegangannya menjadi $12 \mathrm{~V}$ DC. Saat tegangan pada akumulator melemah (kurang dari 12V), maka secara otomatis rangkaian pengisi akan terhubung ke terminal akumulator. Bila tegangan baterry sudah penuh (mencapai $\pm 12 \mathrm{~V}$ ), maka secara otomatis rangkaian pengisi akan memutuskan hubungan catu daya ke terminal battery. Sedangkan pada rangkaian pengubah tegangan DC $12 \mathrm{~V}$ ke tegang- an AC 220V, saat suplai listrik dari PLN tersedia maka seluruh pembebanan berasal dari tegangan PLN $220 \mathrm{~V}$.

Bila terjadi gangguan pada menyebabkan terhentinya suplai listrik dari PLN, maka rangkaian inverter dengan sumber dari akumulator akan menjadi catu daya cadangan walaupun masih dalam pembebebanan yang terbatas. hasilkan :

Besarnya daya listrik yang di

$$
\begin{aligned}
\mathrm{P} & =\mathrm{I} \times \mathrm{V} \\
& =2,7 \times 220
\end{aligned}
$$

$$
=594 \text { watt }
$$

Tegangan efektif yang di hasilkan :

$$
\begin{aligned}
\mathrm{V}_{\text {eff }}=\frac{2 V_{S}}{\sqrt{2 \pi}} & =0.45 \times \mathrm{V}_{\mathrm{s}} \\
& =0,45 \times 220 \mathrm{~V} \\
& =99 \text { watt }
\end{aligned}
$$

Hasil Tabulasi pengujian pada lampu TL 30 watt dan 50 watt

Untuk mengetahui beban lsitrik yang sebenar maka dilakukan pengujian dengan 2 jenis percobaan. Percobaan pertama pada beban 30 watt dan percobaan kedua pada beban listrik 50 watt, Hasilnya bisa di lihat pada table di bawah ini

Tabel Hasil Pengujian 30 watt
\begin{tabular}{|c|c|c|c|c|c|c|c|}
\hline No & $\begin{array}{c}\text { Teg. Input } \\
\text { DC } \\
\text { (volt) }\end{array}$ & $\begin{array}{c}\text { Arus } \\
\text { Output DC } \\
\text { (ampere) }\end{array}$ & $\begin{array}{c}\text { Tegangan } \\
\text { Output Alat } \\
\text { AC (volt) }\end{array}$ & $\begin{array}{c}\text { Arus } \\
\text { Beban } \\
\text { (amper) }\end{array}$ & $\begin{array}{c}\text { Beban } \\
\text { Terpasang } \\
\text { (Watt) }\end{array}$ & $\begin{array}{c}\text { Beban Lampu } \\
\text { Terukur } \\
\text { (Watt) }\end{array}$ & $\begin{array}{c}\text { Analisis } \\
\text { Beban } \\
\text { (Watt) }\end{array}$ \\
\hline 1 & 12 & 2.7 & 210 & 0.31 & 30 & 31 & 30.1 \\
\hline 2 & 12 & 2.5 & 212 & 0.31 & 30 & 29 & 30.2 \\
\hline 3 & 11.5 & 2.4 & 212 & 0.30 & 30 & 29 & 29.3 \\
\hline 4 & 11.3 & 2.4 & 211 & 0.30 & 30 & 28 & 28.3 \\
\hline 5 & 11.1 & 2.3 & 211 & 0.31 & 30 & 29 & 29.3 \\
\hline
\end{tabular}

Tabel Sedangkan untuk pengujian 50 watt dapat di lihat padatabel berikut di bawah ini

Tabel| Hasil Pengujian 50 watt

\begin{tabular}{|c|c|c|c|c|c|c|c|}
\hline No & $\begin{array}{c}\text { Teg. Input } \\
\text { DC } \\
\text { (volt) }\end{array}$ & $\begin{array}{c}\text { Arus } \\
\text { OutputDC } \\
\text { (ampere) }\end{array}$ & $\begin{array}{c}\text { Tegangaan } \\
\text { Oupput Alat } \\
\text { AC(volt) }\end{array}$ & $\begin{array}{c}\text { Arus } \\
\text { Beban } \\
\text { (amper) }\end{array}$ & $\begin{array}{c}\text { Beban } \\
\text { Terpasang } \\
\text { (Waat) }\end{array}$ & $\begin{array}{c}\text { Beban Lampu } \\
\text { Terukur } \\
\text { (Watt) }\end{array}$ & $\begin{array}{c}\text { Analisis } \\
\text { Beban } \\
\text { (Waat) }\end{array}$ \\
\hline 1 & 12 & 4.8 & 213 & 0.32 & 60 & 62 & 63.1 \\
\hline 2 & 12 & 4.8 & 213 & 0.31 & 60 & 59 & 62.2 \\
\hline 3 & 11.1 & 4.6 & 213 & 0.31 & 60 & 59 & 61.3 \\
\hline 4 & 11.1 & 4.6 & 211 & 0.32 & 60 & 59 & 60.3 \\
\hline 5 & 11.1 & 4.6 & 211 & 0.31 & 60 & 59 & 60.3 \\
\hline
\end{tabular}

Sumber: Pengolahan data

\section{Perhitungan Daya Baterai}

Dalam perhitungan beban diketahui bahwa daya yang harus di sediakan untuk mengisi 10 unit alat elektronik dengan kapasitas baterai masing masing $2000 \mathrm{mAh}$ adalah 100 watt per jam, jadi perhitungan daya baterai untuk sistem yang direncanakan menurut perhitungan sebagai berikut :

2 Buah baterai Lithium Ion $11.2 \mathrm{~V}$ dengan kapasitas $2600 \mathrm{mAh}$ perbuah 
disusun parallel maka menghasilkan baterai dengan kapasitas 51.200 mAh atau $51.2 \mathrm{Ah}$

$$
\begin{aligned}
& I=51.2 \mathrm{~A} \\
& V=11.2 \mathrm{~V} \\
& P=51.2 \times 11.2 \\
& P=573,44 \text { watt per jam }
\end{aligned}
$$

Pada daya yang dibutuhkan untuk pengisian 10 unit alat elektronik portabel dengan kapasitas baterai 2000 mAh per buah secara bersamaan adalah 100 watt per jam dengan kondisi seluruh unit dengan baterai keadaan kosong, dan baterai dari sistem rancang bangun memiliki kapasitas 131 watt per jam untuk melakukan pengisian. Karena perbedaan voltase baterai dan sistem maka digunakan modul $d c$ voltage step up untuk menaikan voltase pada $5 \mathrm{v}$. Modul ini memiliki efesiensi 95\% maka daya baterai sistem adalah sebesar 124.45 watt per jam

\section{KESIMPULAN}

Berdasarkan hasil analisa dan perhitungan yang telah dilakukan pada penerangan hasil rancangan dengan memperhatikan rumusan masalah dapat diambil kesimpulan sebagai berikut :

- Daya yang dihasilkan sebesar 574 W.

- Lama pengisian yang dihasilkan selama 4.6 jam

- Intensitas Cahaya 0,7

- Total daya 1450 Watt.

\section{REFERENSI}

[1] Achmad Zainuri, (2011), Elemen Mesin III, Jurusan Teknik Mesin Fakultas Teknik Universitas Mataram.

[2] Astu Pudjanarsa, Djati Nursuhud, (2008), Mesin Konversi Energi, Penerbit ANDI, Surabaya.

[3] Dian Aksara, Komunitas. (2007), Energi Alternatif, Ghalia Indonesia, Jakarta
[4] Drs, Daryanto, (2000), Teknik Pengerjaan Listrik, Bumi Aksara, Jakarta.

[5] F. Suryatmo, (1996). Dasar-dasar Teknik Listrik, Jakarta : Rineka Cipta.

[6] Nanang Arif Guntoro, (2013), Fisika Terapan, PT. Remaja Rosdakarya, Bandung.

[7] Richard Blocher, (2004), Dasar Elektronika, Penerbit ANDI, Yogyakarta

[8] Victor Uji Kurnia, (2013), "Pengertian arus listrik AC dan DC beserta contoh penggunaannya". 